\title{
Adhesive properties of food and faecal potential probiotic lactobacilli
}

\author{
Tejpal Dhewa ${ }^{*}$, Shailja Pant, Nishant Goyal ${ }^{1}$ and Vijendra Mishra ${ }^{2}$ \\ Department of Microbiology, Dolphin (PG) Institute of Biomedical and Natural Sciences, Dehradun -248007 (Uttarakhand), INDIA \\ ${ }^{1}$ Department of Botany and Microbiology, H.N.B. Garhwal University, Srinagar (Uttarakhand), INDIA \\ ${ }^{2}$ Department of Dairy Microbiology, Anand Agricultural University, Anand-388 001 (Gujrat), INDIA \\ *Corresponding author. E-mail: tejpal_dhewa07@rediffmail.com
}

\begin{abstract}
In the present investigation, total four isolates of Lactobacillus species i.e. L. casei, L. helveticus, L. brevis and $L$. fermentum were examined for the cell surface hydrophobicity by bacterial adherence to hydrocarbons assay in LAPTg broth and hydrophobicity was calculated as percentage decrease in Optical Density at $600 \mathrm{~nm}$. The general range of hydrophobicity in Lactobacilli was found in between 6-73\%. Remarkably, $L$. helveticus and $L$. fermentum showed $73 \%$ hydrophobicity in xylene. Higher value of hydrophobicity could point toward a better ability of lactobacilli to adhere to epithelium cells. The outcome of present study concludes that $L$. helveticus and $L$. fermentumhave good adhesive properties which may help them to adhere to surface epithelium of host cell and further screening with other probiotic attributes could be designated as probiotics.
\end{abstract}

Keywords: Lactobacillus, Probiotic, Hydrophobicity, Optical density.

\section{INTRODUCTION}

Lactobacilli are considered potentially probiotic organism because of its ability to adhere host tissue and prevents the colonization of enteric pathogen. These are a part of the normal flora of human and animal oral cavity, vaginal and gastrointestinal tract. They are extensively used in the production of different kind of health promoting fermented food, beverage and vegetables. Due to their anticipated health promoting properties, Lactobacillus species are mostly used as a probiotic (Ouwehand et al., 2002 and Puniya et al., 2008). Probiotic is a microbial feed supplement that exerts beneficial effects for the host in improvement of the microbiological balance in the intestine (Fuller, 1989). Development of a probiotic product is dependent on strains that fulfill the strict criteria of: human origin, possession of generally regarded as safe (GRAS) status, production of antibacterial factors against invasive gram negative pathogens, desirable metabolic activity, technological suitability, nonpathogenic, immune-stimulatory, anti-carcinogenic, anti-mutagenic etc. (Fuller and Gibson, 1997 and Drisko et al., 2003).

An important property supposed for a probiotic bacterium is the ability to adhere and colonize host tissues, which enhances reproduction and survival of bacteria in the host and inhibits colonization by pathogenic bacteria. Inhibition of the multiplication of pathogen can be through production of antimicrobial components such as organic acid-Lactic acid, acetyl, hydrogen peroxide and bacteriocins (Jin et al., 1996). The mechanism by which Lactobacillus acidophilus adheres to the human gastrointestinal tract has been partially elucidated (Coconnier et al., 1992; Reid et al., 1993; Aleljung et al., 1994). Beside this cell surface lectin like proteins have been found in many bacterial species and have been suggested to play an important role in the defense, adhesion, and recognition of bacterial cells (Isberg and Barnes, 2002). The presence of various lectins like substances in the outer cell layer of L. acidophilus thought to contribute to cell adhesion through their binding to carbohydrate portions of the colonic mucus layer (Satio, 2004). It has been suggested that lectin like substances in surface layered proteins (SLP) of lactobacilli play an important role in adhesion to receptors, such as sugar chains of glycolipids (Yamamoto et al., 1996) or glycoprotein's (Gusils et al., 1999; Matsumura et al.,1999 and Annuk et al., 2001), on the surfaces of intestinal epithelial cells. The present investigation is an analysis of cell surface hydrophobicity characteristics of four strains of Lactobacillus species, isolated from the indigenous and exogenous sources has been carried out.

\section{MATERIALS AND METHOD}

Source and maintenance of cultures : Lactobacilli strain used in this study were L. casei, L. helveticus, $L$. brevis and L. fermentum. These are of food (exogenous) and human faecal (indigenous) isolates. The standard culture of Mycobacterium smegmatis MTCC 6 was procured from Microbial Type Culture Collection, IMTech Chandigarh, India. Lactobacillus acidophilus NCDC 15 was procured from National Collection of Dairy Cultures NDRI Karnal Harayana, India. Before experiments, lactic cultures were sub-cultured at regular intervals in chalk 
litmus milk and stored under refrigeration conditions. Before use the cultures were activated in de Mann Rogosa Sharpae (MRS) broth. The culture of $M$. smegmatis MTCC 6 was maintained at refrigeration temperature in Lowenstein-Jensen (L.J.) medium. Before use cultures were activated in their respective fresh medium and checked for purity by microscopic examinations.

Cell surface hydrophobicity: The ability of organisms to adhere selected hydrocarbons was determined by the method of hydrophobicity assay (Rosenberg et al., 1982) with some modifications. The test bacterium was grown in LAPTg broth using $M$. smegmatis as a positive control and L.acidophilus is a negative control, harvested after $24 \mathrm{hrs}$ by centrifugation at $12000 \mathrm{rpm}$ for $5 \mathrm{~min}$ at $5^{\circ} \mathrm{C}$ washed twice in $50 \mathrm{mM}$ $\mathrm{KH}_{2} \mathrm{PO}_{4}(\mathrm{pH} 6.5$ ) buffer and finally suspended in same buffer. The cell suspension was adjusted to $\mathrm{OD}_{600} \mathrm{~nm}$ of approximately 1.0 with buffer and to $3 \mathrm{~mL}$ of bacterial suspension $1 \mathrm{~mL}$ of test hydrocarbons (n-hexadecane, xylene and toluene) was added. The mixtures were vortexes for $90 \mathrm{sec}$. The tubes were allowed to stand for separation of two phases and $\mathrm{OD}_{600} \mathrm{~nm}$ of aqueous phase was measured. Hydrophobicity was calculated from percentage decrease in optical density of original bacterial suspension due to partitioning was calculated by equation:

Percent Hydrophobicity $(H \%)=\left(O . D_{600}\right.$ before mixing O.D. $_{600}$ after mixing)/(O.D. ${ }_{600}$ before mixing) x 100.

\section{RESULTS AND DISCUSSION}

The adhering ability of lactobacilli studied in vitro by calculating the reduction in absorbance of buffer containing cellular suspension indicated that there was a vast difference in the hydrophobicity. L. helveticus of faecal origin revealed $73 \%$ hydrophobicity in xylene, $69 \%$ in toluene, and $37 \%$ in n-hexadecane, while L. fermentum showed $73 \%$ hydrophobicity in xylene, $68 \%$ in toluene, and $37 \%$ in $n$ - hexadecane (Table 1). The isolates of food origin, $L$. casei and L. brevis showed in $21 \%$ to $52 \%$ value ranges of hydrophobicity. The higher value of cell surface hydrophobicity of $L$. helveticus and L. fermentum in three different hydrocarbons i.e. xylene, toluene and $\mathrm{n}$-hexadecane were obtained.

Determination of microbial adhesion to hydrocarbons as a way to estimate the ability of strain to adhere to epithelial cells is a valid qualitative phenomenogical approach and considered one of the most important characteristics of probiotic lactic acid bacteria for their further probiotic action. Adhesion verifies the potential of the strain to inhibit the intestinal tract and to grow in intestinal conditions. Ly et al. (2008) confirmed that bacteria possess physicochemical surface properties such as hydrophobicity, Lewis acid/base and charge
Table 1. Hydrophobicity of lactobacillus species as determined in selected hydrocarbons.

\begin{tabular}{lccc}
\hline \multicolumn{1}{c}{ Organism } & \multicolumn{3}{c}{ Hydrophobicity in\% $^{\mathrm{a}}$} \\
\cline { 2 - 4 } & n-Hexadecane & Xylene & Toluene \\
\hline L c casei & $21 \pm 4^{\mathrm{b}}$ & $28 \pm 3$ & $27 \pm 8$ \\
L. brevis & $28 \pm 3$ & $52 \pm 3$ & $40 \pm 4$ \\
L. helveticus & $37 \pm 10$ & $73 \pm 3$ & $69 \pm 4$ \\
L. fermentum $_{\text {M. smegmatis MTCC 6 }}{ }^{\mathrm{c}}$ & $36 \pm 10$ & $73 \pm 3$ & $68 \pm 4$ \\
L. acidophilus NCDC 15 $^{\mathrm{d}}$ & $70 \pm 3$ & $86 \pm 4$ & $78 \pm 3$ \\
\hline
\end{tabular}

a \% Hydrophobicity = (O.D.600 before mixing - O.D. ${ }_{600}$ after mixing)/ (O.D. ${ }_{600}$ before mixing) x 100; ${ }^{\mathrm{b}}$ Mean \pm S.D, $(\mathrm{n}=5) ;{ }^{\mathrm{c}}$ Positive control; ${ }^{\mathrm{d}}$ Negative control

which are involved in physicochemical interactions between cells and interfaces. The mechanism of microbial adhesion to surfaces can be explained by two sequential step event (Perers et al., 1977; Handley et al., 1987; Lindahl et al., 1981 and Norde and Lyklemm, 1993) e.g. reversible adhesion due to long range forces (Derjaguin and Lanadau, 1941), and possibly subsequent interactions that mediate a direct contact between surfaces, such as hydrophobic interactions due to bacterial surface structures (Busscher and Weerkamp, 1987 and Gusils et al., 1999).

In our study, L. helveticus and L. fermentum exhibited significantly higher cell surface hydrophobicity than $L$. casei and $L$. brevis. The high values of hydrophobicity could be a sign of a greater capability of bacteria to adhere the epithelial cells as indicated by Rosenbergetal. (1980). The strains e.g. L. casei and L. brevis showed low value of hydrophobicity designate a low ability of bacterial adhesion to host intestinal epithelium cells. The results obtained in the present study are in agreement with that of Vindderola (2003) who observed the hydrophobicity values for probiotic strains, found ranged from 38.1 to $67.8 \%$ (L. acidophilus) from 13.6 to $64.7 \%$ (Bifidobacteria) and from 10.9 to only $24.1 \%$ for the strains of $L$. casei and $L$. rhamnosus. In our work, the highest value of hydrophobicity was found for the L. helveticus ranged from 37 to $73 \%$. It was interesting to see that hydrophobicity of L. helveticus and L. fermentum were slightly higher than reported by Vindderola (2003) for probiotic organisms. The findings of present study indicated that L. helveticus and L. fermentum have good adhesive properties which may help them to adhere to surface epithelium of host cell. These strains are being further investigated in our laboratory for other probiotic attributes. After screening, these cultures could be selected as probiotics and can be incorporated in commercially available dairy products to maximize health benefits. 


\section{ACKNOWLEDGEMENTS}

The authors thank Dolphin (PG) institute of Biomedical and Natural Sciences, Dehradun -248007, Uttarakhand for funding this research work.

\section{REFERENCES}

Aleljung, P., Shen, W., Rozalska, B., Hellman, U., Ljungh, A. and Wadstrom, T. (1994). Purification of collagen-binding proteins of Lactobacillus reuteri NCIB 11951. Current Microbiology, 55:1100-1105.

Annuk, H., Hynes, S.O., Hirmo, S., Mikelsaar, M. and Wadstrom, T. (2001). Characterization and differentiation of lactobacilli by lectin typing. Journal of Medical Microbiology, 50:1069-1074.

Busscher, H. I. and Weerkamp, A. H. (1987). Specific and non-specific interactions in bacterial adhesion to solid substrata. FEMS Microbiology Reviews, 46:165-173.

Coconnier, M.H., Klaenhammer, T.R., Kerneis, S., Bernet, M.F. and Servin, A.L. (1992). Protein-mediated adhesion of Lactobacillus acidophilus BG2FO4 on human enterocytes and mucus-secreting cell lines in culture. Applied Environmental Microbiology, 58:2034-2039.

Derjaguin, B. V. and Lanadau, L. (1941). Theory of the stability of strongly charged lyophobic sols and the adhesion of strongly charged particles in solutions of electrolytes. Acta Physiochimica, 14:633-662.

Drisko, J. A., Giles, C. K. and Bischoff, B. J. (2003). Probiotics in health maintenance and disease prevention. Alternative Medicine Review, 8(2): 143-155.

Fuller, R. (1989). Probiotics in man and animals. Journal of Applied Bacteriology, 66:365-378.

Fuller, R. and Gibson, G. R. (1997). Modification of the intestinal micro flora using Probiotics and Prebiotics. Gastroenterology, 32(222):28 31.

Gusils, C., Perez Chaia, A., Gonzalez, S. and Oliver, G. (1999). Lactobacilli isolated from chicken intestines: Potential use as Probiotics. Journal of Food Production, 62 (3):252-256.

Handley, P. S., Harty, D. W. S., Wyatt, J. E., Brown, C. R., Doran, J. P. and Gibbs, A. C. C. (1987). A comparison of the adhesion, co aggregation and cell-surface hydrophobicity properties of fibrillar and fimbriate strains of Enterococcus salivarius. Journal of General Microbiology, 133:3207-3217.

Isberg, R. R. and Barnes, P. (2002). Dancing with the host: flow dependent bacterial adhesion. Cell, 110:1-4.

Jin, L. Z., Ho, Y. W., Abdullah, N., Ali, M. A. and Jalaludin, S. (1996). Antagonistic effects of intestinal Lactobacillus isolates on pathogens of chicken. Letters in Applied Microbiology, 23:67-71.

Lindahl, M., Faris, A., Wadstrom, T. and Hjerten, S. (1981). A new test based on salting out to measure relative hydrophobicity of bacterial cells. Biochemical and Biophysics Acta, 677:471-476.
Ly, M. H., Aguedo, M., Goudot, S., Le, M. L., Cayot, P., Teixeira, J. A., Le, T. M., Belin, J. M. and Wache, Y. (2008). Interactions between bacterial surfaces and milk proteins, impact on food emulsions stability. Food Hydrocolloid, 22: 742-751.

Matsumura, A., Saito, T., Arakuni, M., Kitazawa, H., Kawai, Y. and Itoh, T. (1999). New binding assay and preparative trial of cell surface lectin from Lactobacillus acidophilus group lactic acid bacteria. Journal of Dairy Science, 82:25252529.

Norde, W. and Lyklemm, J. (1993). Protein adsorption and bacterial adhesion to solid surfaces: a colloid- chemical approach. Colloids and Surfaces A, 38:1-13.

Ouwehand, A. C., Salminen, S. and Isolauri, E. (2002). Probiotics: An overview of beneficial effects. Antonie Van Leeuwenhoek, 82:279-289.

Perers, L. L., Andaker, L., Edebo, O., Stendahl and Tagesson, C. (1977). Association of some enterobacteria with the intestinal mucosa of mouse in relation to their partition in aqueous polymer two-phase systems. Acta Pathologica ET Microbiologica Scandinavica Section B, 85:308-316.

Puniya, A.K., Puniya, M., Nagpal, R., Malik, M., Kumar, S., Mishra, V., Dhewa T., Pant, S. and Singh, K. (2008). Functional dairy Foods: A healthy hope. In: A. Kumar, G. Sahal, and R. P. Kaur (Eds.), Lecture Notes: Workshop on Biotechnology Education (pp.195-205). Dehradun: Saraswati Press.

Reid, G., Serivin, A. L., Bruce, A. W. and Busscher, H. J. (1993). Adhesion of three Lactobacillus strains to human urinary and intestinal epithelial cells. Micro-bioscience, 75:57-65.

Rosenberg, M., Bayer, E. A., Delarea, J. and Rosenberg, E. (1982). Role of thin fimbriae in adherence and growth of Acinetobacter calcoaceticus on hexadecane. Applied and Environmental Microbiology, 44:929-937.

Rosenberg, M., Gutnick, D. and Rosenberg, E. (1980). Adherence of bacteria to hydrocarbons: A simple method for measuring cell surface hydrophobicity. FEMS Microbiology Letters, 9:28-33.

Satio, T. (2004). Selection of useful Probiotics lactic acid bacteria from the Lactobacillus acidophilus group and their application to functional foods. Rev. Art. Animal Science Journal, 75:1-13.

Vindderola, C. G. and Reinheimer, J. A. (2003). Lactic acid starter and probiotic bacteria: A comparative in vitro study of probiotic characteristics and biological barrier resistance. Food Research International, 36:895-904.

Yamamoto, K., Miwa, T., Taniguchi, H., Nagano, T., Shimamura, K., Tanaka and Kumagai, T. (1996). Binding specificity of Lactobacillus to glycolipids. Biochemical and Biophysical Research Communications, 228:148-152. 